\title{
How soil characteristics and water quality influence the biogeochemical response to flooding in riverine wetlands
}

\author{
Roos Loeb · Erika van Daalen · Leon P. M. Lamers • \\ Jan G. M. Roelofs
}

Received: 29 September 2006/ Accepted: 18 May 2007/Published online: 27 July 2007

(C) Springer Science+Business Media B.V. 2007

\begin{abstract}
Although phosphate concentrations have been reduced, the rivers Meuse and Rhine are still polluted with sulphate, which most probably affects vegetation development in newly created riverine wetlands. The influence of flooding with river water rich in sulphate was tested on three soil types from floodplains of the river Meuse using flow-through and batch experiments. Soils were selected for contrasting concentrations of iron and organic matter and originated from a floating fen (iron-poor, organic), an alder carr (iron-rich, organic) and a clay pit (ironrich, low in organic matter). Flooding induced mobilisation of phosphate. Sulphate only enhanced this effect in the alder carr soil, where sulphide and phosphate competed for binding to iron. Only in the floating fen soil did the addition of sulphate result in the formation of free sulphide, which reduced the growth of Glyceria maxima, serving as a phytometer. In addition, the floating soil started to sink, due to falling methane concentrations. In the different soil types methane production was hampered by the presence of more favourable electron acceptors such as sulphate in the water and $\mathrm{Fe}$ (III) in the soil. It was
\end{abstract}

R. Loeb $(\bowtie) \cdot$ E. van Daalen · L. P. M. Lamers .

J. G. M. Roelofs

Department of Aquatic Ecology and Environmental Biology, Institute for Water and Wetland Research, Radboud University Nijmegen, Toernooiveld 16525 ED,

The Netherlands

e-mail: r.loeb@science.ru.nl concluded that the effects of inundation with sulphate-polluted water strongly depend on the soil type: under iron-poor circumstances, free sulphide may accumulate, leading to phytotoxicity, while in soils rich in iron, sulphide toxicity is prevented, but phosphate availability may be increased. In addition, shortage of easily degradable organic matter can limit the formation of potential toxicants such as ammonium, iron and sulphide. Results are discussed in terms of their implications for nature management.

Keywords Buoyancy - Eutrophication · Flooding · Floodplain · Methane $\cdot$ Sulphate $\cdot$ Water storage

\section{Introduction}

Although great efforts have been made since the 1970s to improve water quality in the rivers Meuse and Rhine, concentrations of many major ions are still elevated compared to their natural background values. Measures such as the introduction of wastewater treatment plants have effectively reduced the concentrations of ammonium and phosphorus in the river water, and decreased discharge from the industry and decreased atmospheric sulphur deposition have contributed to a decrease in concentrations of sodium, chloride and sulphate, respectively. However, today's average sulphate concentrations in the river Meuse still lie around $600 \mu \mathrm{mol} \mathrm{l}^{-1}$ (Waterstat 2006), whereas measured historical concentrations 
(before 1900) and calculated background concentrations for the Meuse and Rhine in the Netherlands are approximately $300 \mu \mathrm{mol} 1^{-1}$. Concentrations of nitrate (around $50 \mu \mathrm{mol} 1^{-1}$ ) are also still elevated compared to their background values $\left(5 \mu \mathrm{mol} \mathrm{l}^{-1}\right)$ (Van der Weijden and Middelburg 1989; Van den Brink et al. 1991; Van den Brink 1994). This article focuses on the effects of the elevated sulphate concentrations.

It is known that sulphate pollution can play an important role in the deterioration of freshwater wetlands, especially in peatlands (Roelofs 1991; Smolders et al. 1996, 2003; Lamers et al. 1998, 1999, 2001, 2002a, b; Lucassen et al. 2004). Under anaerobic circumstances, for instance during flooding, sulphate is reduced to sulphide in the absence of more favourable electron acceptors such as oxygen or nitrate. Free sulphide can be very toxic to wetland plant species, as has for instance been shown for Stratiotes aloides (Smolders and Roelofs 1996) and Caltha palustris (Van der Welle et al. 2007). However, sulphide has a high affinity for binding to iron, which decreases the availability of free sulphide and hence its toxicity (Van der Welle et al. 2006). As the affinity to iron is higher for sulphide than for phosphate, the latter can be released during this process, causing eutrophication (Caraco et al. 1989; Roden and Edmonds 1997; Lamers et al. 1998). This mobilisation of phosphate is added to the release of phosphate that takes place upon reduction of iron after the flooding of semi-terrestrial wetlands, such as floodplains. After inundation and the depletion of oxygen from the pore water, iron can be used as an electron acceptor for the oxidation of organic matter. This causes a partial release of the phosphate that was bound to iron(hydr)oxides under aerobic circumstances (Patrick and Khalid 1974). It is, however, unclear if sulphate has similar detrimental effects on floodplain biogeochemistry.

Besides the phytotoxic and eutrophying effects of sulphate after reduction, sulphate is also known to inhibit bacterial methane production (Cappenberg 1974; Abram and Nedwell 1978; Lovley and Klug 1983; Westermann and Ahring 1987; Prieme 1994; Scholten and Stams 1995). It has been demonstrated that as a result of this, floating Sphagnum bog rafts, which depend on methane for floatation, sink under the influence of increased sulphate concentrations (Lamers et al. 1999; Smolders et al. 2002). As floating fen mats present in riverine systems also depend on methane for buoyancy (Hogg and Wein 1988a; Swarzenski et al. 1991; Sasser et al. 1996), a similar effect of elevated sulphate concentrations can be assumed to exist, although this has never been reported. Floating mats form an important phase in terrestrialisation and hence in vegetation succession of peatlands (Tallis 1973; Beltman et al. 1996). They can be found in river deltas across the world, such as in the rivers Mississippi, Danube, Nile and Amazon (Hogg and Wein 1988b; Sasser et al. 1996).

During the last decade, many new wetlands have been created in the floodplains of large rivers, including the rivers Rhine and Meuse, either for the purpose of ecological restoration, or for flood risk reduction, or for a combination of both objectives. Plans for riverine wetland creation often ignore river water quality and soil quality, although it may be hypothesised that the effects of sulphate pollution that have been found in peatlands may also play an important role in riverine floodplains. Since concentrations of iron and of easily degradable organic matter are expected to act as key factors differentiating the effects of sulphate pollution, we chose to examine three different floodplain soils from the river Meuse, differing in iron and organic matter contents.

\section{Materials and methods}

\section{Site description}

Three different floodplain areas along the river Meuse in the Netherlands were selected for their soil characteristics. Figure 1 depicts the locations of the sites. The first soil (F) was taken from a floating fen at the bank of an old oxbow lake (the 'Oude Maas') anchored to the river dike ( $\mathrm{N} 47^{\circ} 58^{\prime} 43.04^{\prime \prime} \mathrm{E}$ $\left.3^{\circ} 18^{\prime} 56.38^{\prime \prime}\right)$. This lake discharges its water into the Meuse and only comes into direct contact with the river water during floods. The soil consists mostly of roots and plant litter. The vegetation type it supports, which is dominated by the fern Thelypteris palustris, has become very rare in Dutch floodplains. A vegetation relevé from 1954 shows that at that time, the oxbow lake was partly vegetated by Stratiotes aloides (Van Donselaar 1961). The second soil (C) was taken from the shores of a recently dug clay pit (N $47^{\circ} 58^{\prime} 41.42^{\prime \prime}$ E $\left.318^{\prime} 58.26^{\prime \prime}\right)$ in the 


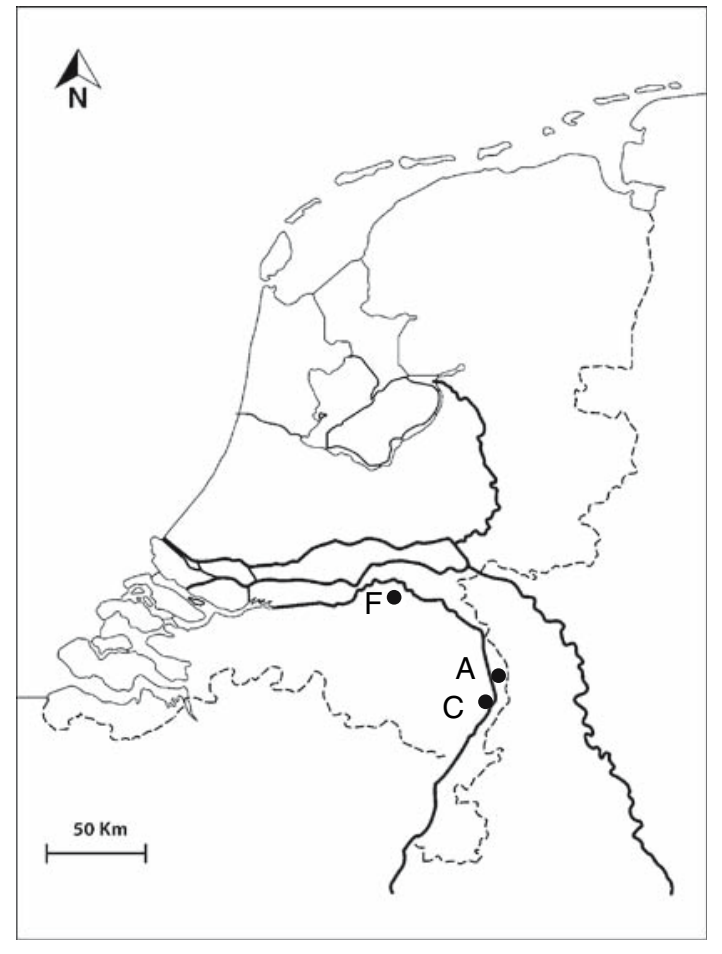

Fig. 1 Location of the sampling sites within the Netherlands. $\mathrm{A}=$ alder carr, $\mathrm{C}=$ clay pit, $\mathrm{F}=$ floating fen

Romeinenweerd nature reserve. In this area, several small lakes have been excavated for the purpose of nature restoration and flood risk reduction. The excavated clay was used for the construction of flood protection systems in neighbouring towns. The lake from which we collected the soil, is a stagnant water body, which suffered severe eutrophication in the hot summer of 2003, when a bloom of cyanobacteria led to high mortality of fish and waterfowl (Pollux and Pollux 2004). No vegetation was present at the spot from which we took the soil. The third soil (A) was taken from a black alder carr (N 47 58'42.27" E $\left.3^{\circ} 18^{\prime} 57.98^{\prime \prime}\right)$, called Heuloërbroek, within the winter bed of the river Meuse. The site receives discharge of iron-rich groundwater from higher situated areas. The top soil consists of litter, mainly from Alnus glutinosa.

Soil characteristics are summarised in Table 1. The clay soil was poor in organic matter (about 5\%), while the other two soils were mostly organic. Both the alder carr and clay soils had a high concentration of iron, but the oxalate-extractable pool, which is regarded as the amorphous iron that is available for bacterial reduction, was much lower in the clay soil, both in absolute and in relative terms. The iron concentration of the floating fen soil was very low. Both total $\mathrm{P}$ and Olsen-extractable $\mathrm{P}$ were high in the alder carr soil.

\section{Experimental set-up}

\section{Aquarium experiment}

Twenty-four 9-1 aquaria were filled with a $10-\mathrm{cm}$ layer (1/3 of the aquarium) of carefully mixed soil (four replicates) (Fig. 2) and kept in a water basin at a temperature of $20^{\circ} \mathrm{C}$ in a climate chamber at a light intensity of $200 \mu \mathrm{mol} \mathrm{m} \mathrm{m}^{-2} \mathrm{~s}^{-1}$ (Hortilux Schreder HPS $400 \mathrm{~W}$ ) for $12 \mathrm{~h}$ a day. Two $10-\mathrm{cm}$ pore water samplers (Rhizon SMS -10 cm; Eijkelkamp Agrisearch Equipment, The Netherlands) were placed diagonally in the soil of each aquarium. A 5-10 cm layer of surface water collected in the field was added on top of the soil. After 1 week, the soils were further inundated with artificial river water containing either $1 \mathrm{mmol} \mathrm{l}^{-1} \mathrm{SO}_{4}$ (as $\mathrm{Na}_{2} \mathrm{SO}_{4}$ ) or no $\mathrm{SO}_{4}$ (Table 2), from 101 stocks, each connected to their own aquarium. The medium was pumped through the aquaria at a speed of 101 per week. Three shoots of Glyceria maxima and $0.25 \mathrm{~g}$ of Lemna minor, collected in the field, were added to each aquarium as phytometers. Other plant species than G. maxima, L. minor or algae were carefully removed from the aquaria. Pore water samples were taken by connecting 100-ml vacuum bottles to the rhizon samplers. Samples of both pore water samplers were pooled per aquarium to diminish the effects of heterogeneity. Surface water samples were filtered (Whatman GF/ C). After 12 weeks, the aboveground biomass of $G$. maxima and the floating $L$. minor and algae biomass were harvested. In the aquaria with the alder carr soil, algae were harvested more often, to prevent die-off of G. maxima from light limitation.

\section{Decomposition experiment}

Fifty g portions of fresh soil were transferred to 350$\mathrm{ml}$ glass bottles. The bottles were filled up to $170 \mathrm{ml}$ with the same medium as used in the aquarium experiment and preflushed with $\mathrm{N}_{2}$ to remove $\mathrm{O}_{2}$ from the water. The headspace of the bottles was also flushed with $\mathrm{N}_{2}$ before they were sealed with airtight 
Table 1 Soil characteristics

\begin{tabular}{llllll}
\hline Soil & $\begin{array}{l}\text { Organic matter } \\
\text { content }(\%)\end{array}$ & $\begin{array}{l}\text { Oxalate-extractable } \\
\mathrm{Fe}\left(\mu \mathrm{mol} \mathrm{g}^{-1} \mathrm{dw}\right)\end{array}$ & $\begin{array}{l}\text { Total Fe } \\
\left(\mu \mathrm{mol} \mathrm{g} \mathrm{g}^{-1} \mathrm{dw}\right)\end{array}$ & $\begin{array}{l}\text { P-Olsen } \\
\left(\mu \mathrm{mol} \mathrm{g}^{-1} \mathrm{dw}\right)\end{array}$ & $\begin{array}{l}\text { Total P } \\
\left(\mu \mathrm{mol} \mathrm{g} \mathrm{g}^{-1} \mathrm{dw}\right)\end{array}$ \\
\hline $\begin{array}{l}\text { Floating } \\
\text { fen }\end{array}$ & 83 & 50 & 100 & 3 & 30 \\
Clay pit & 5 & 104 & 610 & 1 & 24 \\
$\begin{array}{c}\text { Alder } \\
\text { carr }\end{array}$ & 52 & 950 & 1011 & 5 & 104 \\
\hline
\end{tabular}

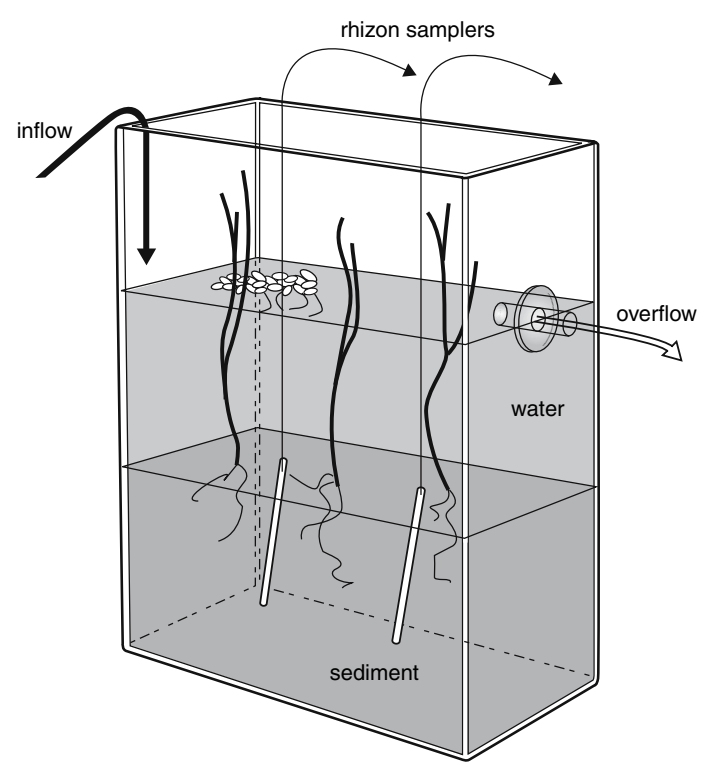

Fig. 2 Experimental set-up. Picture: Lidwien van der Horst

Table 2 Concentrations of macro-ions in the artificial river water treatments, with and without sulphate

\begin{tabular}{|c|c|c|}
\hline & 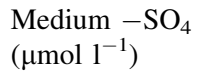 & $\begin{array}{l}\text { Medium }+\mathrm{SO}_{4} \\
\left(\mu \mathrm{mol} \mathrm{1^{-1 } )}\right.\end{array}$ \\
\hline $\mathrm{Na}$ & 2,000 & 4,000 \\
\hline $\mathrm{Ca}$ & 1,300 & 1,300 \\
\hline $\mathrm{Mg}$ & 250 & 250 \\
\hline $\mathrm{Cl}$ & 3,100 & 3,100 \\
\hline $\mathrm{HCO}_{3}$ & 2,000 & 2,000 \\
\hline $\mathrm{SO}_{4}$ & 0 & 1,000 \\
\hline
\end{tabular}

rubber stoppers. We will refer to this soil and water suspension as slurry. Analyses were done in quadruplicate. Initial concentrations in the slurry water were determined by filling smaller bottles with $25 \mathrm{~g}$ of fresh soil and filling them up to $85 \mathrm{ml}$ with medium. These bottles were shaken overnight. Slurry water samples were taken by pore water samplers (Rhizon
SMS-5 cm; Eijkelkamp Agrisearch Equipment, The Netherlands). Decomposition bottles were shaken in the dark at $20^{\circ} \mathrm{C}$. Samples from the headspace were taken twice a week with 1-ml syringes and were analysed instantly for $\mathrm{CH}_{4}$ and $\mathrm{CO}_{2}$. After 42 days, slurry water samples were taken and the experiment was ended. Potential production rates were calculated by linear regression of the net production in the linear phase of the production rate of $\mathrm{CH}_{4}$ or $\mathrm{CO}_{2}$. Potential decomposition rates were calculated in the same way, expressed as the $\mathrm{C}$ production rates in the linear phase of the concentration build-up of the sum of $\mathrm{CH}_{4}$ and $\mathrm{CO}_{2}$. This does not equal the sum of the potential $\mathrm{CH}_{4}$ and $\mathrm{CO}_{2}$ production rates, because of the difference in lag phase. Potential net release rates were calculated from the difference between the pore water concentrations at the start and the end of the experiment, divided by the time elapsed.

\section{Chemical analyses}

Immediately after collection of the pore water, the concentration of free sulphide was determined in a $10 \mathrm{ml}$ subsample, fixed with $\mathrm{S}^{2-}$ antioxidant buffer containing $\mathrm{NaOH}$, NaEDTA and ascorbic acid (Van Gemerden 1984). $\mathrm{S}^{2-}$ was detected using an $\mathrm{S}^{2-}$ ionspecific Ag electrode and a double junction calomel reference electrode (Thermo Orion) (Van Gemerden 1984). pH was measured with a radiometer Copenhagen type PHM 82 standard $\mathrm{pH}$ meter. Alkalinity was determined by titrating $10 \mathrm{ml}$ of sample with $0.01 \mathrm{mmol}^{-1} \mathrm{HCl}$ down to $\mathrm{pH}$ 4.2. For the ICP analyses, $1.7 \%$ of concentrated nitric acid was added to the samples to keep the oxidised iron in solution. Samples were stored in polypropylene tubes at $4{ }^{\circ} \mathrm{C}$. For the other analyses, $0.12 \mathrm{~g}$ citric acid/ 1 was added to the samples. They were stored in iodated polyethylene bottles at $-24^{\circ} \mathrm{C}$ until further analysis. Total concentrations of $\mathrm{Ca}, \mathrm{Mg}, \mathrm{P}, \mathrm{Fe}$ and $\mathrm{S}$ were analysed by ICP-MS (X series, Thermo Electron Corporation 
and ICP-OES (IRIS Intrepid II XDL, Thermo Electron Corporation). Total Fe measured in the pore water was assumed to be $\mathrm{Fe}(\mathrm{II})$, since this is the dominant soluble species at the $\mathrm{pH}$ values we measured. Total $\mathrm{S}$ was assumed to be $\mathrm{SO}_{4}$ (if no sulphide was present), as, at the concentrations occurring in our soils, only a very small part will be in organic form. This was confirmed by parallel $\mathrm{SO}_{4}$ analysis of part of the samples with methylthymol blue and $\mathrm{BaCl}_{2}$ (Bran + Luebbe, AutoAnalyser 3, Digital Colorimeter). $o-\mathrm{PO}_{4}$ (Technicon AutoAnalyser II), $\mathrm{NH}_{4}^{+}, \mathrm{NO}_{3}^{-}$ $\left(+\mathrm{NO}_{2}^{-}\right)$and $\mathrm{Cl}^{-}$(Bran + Luebbe AutoAnalyser 3$)$ were analysed colorimetrically using ammonium molybdate, salicylate, hydrazine sulphate and ferriammonium sulphate, respectively. $\mathrm{CO}_{2}$ and $\mathrm{CH}_{4}$ were measured by infrared analysis (ABB Advance Optima Infrared Gas Analyser).

In order to determine the total concentrations of elements in plant and soil materials, $200 \mathrm{mg}$ of homogenised and dried sample was digested for 17 min with $4 \mathrm{ml}$ concentrated $\mathrm{HNO}_{3}$ and $1 \mathrm{ml} \mathrm{30 \%}$ $\mathrm{H}_{2} \mathrm{O}_{2}$ (Milestone microwave MLS 1200 Mega). C and $\mathrm{N}$ concentrations in the plant material $(20 \mathrm{mg})$ were determined with a CNS analyser (Carbo Erla Instruments NA 1500).

Organic matter content of the soils was determined by loss-on-ignition $\left(4 \mathrm{~h}, 550^{\circ} \mathrm{C}\right)$. Soil extractions were performed on fresh soils and corrected for moisture content afterwards, after drying (24 h, $105^{\circ} \mathrm{C}$ ). The concentration of amorphous $\mathrm{Fe}$, which is supposed to represent the fraction available for microbial Fe reduction, was determined by oxalate extraction ( $2.5 \mathrm{~g}$ of soil shaken for $2 \mathrm{~h}$ with $30 \mathrm{ml}$ of a solution containing $16.2 \mathrm{~g}$ of $\left(\mathrm{COONH}_{4}\right)_{2} \cdot \mathrm{H}_{2} \mathrm{O}$ and $10.9 \mathrm{~g}$ of $\left(\mathrm{COOH}_{2}\right) \cdot 2 \mathrm{H}_{2} \mathrm{O}$ per l) (Schwertmann 1964) and plant-available $\mathrm{P}$ by bicarbonate extraction $(5 \mathrm{~g}$ of soil shaken with $100 \mathrm{ml}$ of $\left.0.5 \mathrm{M} \mathrm{NaHCO}_{3}\right)(\mathrm{Olsen}$ et al. 1954).

\section{Statistics}

All concentrations were $\log (+1)$ transformed to improve their fit to a normal distribution, except for floatation measurements. All statistics were calculated with SPSS 13.0 (SPSS Inc., 2004). Effects of time series were tested with GLM repeated measures, using Greenhouse-Geisser corrections if terms of sphericity were not met in Mauchly's sphericity test. Effects of sulphate addition on the specific soil types were assessed with an independent samples $T$-test using data of the last measurement, unless stated otherwise. Effects of sulphate on concentrations and production rates of methane and on iron release were tested with 1tailed tests, because the direction of the effect was already known. Differences between soil types were assessed by univariate ANOVA. Decomposition rates were calculated over the linear range of $\mathrm{CO}_{2}$ or $\mathrm{CH}_{4}$ production by linear regression. Significance was accepted at a confidence level of $P \leq 0.05$.

\section{Results}

Aquarium experiment

\section{Pore water and surface water}

Table 3 summarises the results of the repeated measures analyses of the concentrations of elements and compounds in the pore water and surface water. From this table it can be seen that concentrations changed over time for all elements we measured (time effect). These changes were different for the different soil types, as indicated by the significant time $\times$ soil interactions. Major changes in concentrations are discussed below. Initial concentrations of all measured elements and ions are given in Table 4.

The artificial river water replaced the original surface water in the aquarium within 2 weeks, as was indicated by the $\mathrm{Cl}^{-}$concentration (results not shown), which can be used as an inert tracer. Within 1 month, the river water had penetrated all soil types, even the poorly permeable heavy clay soil, as can be seen from the $\mathrm{Cl}^{-}$concentrations in the pore water (Fig. 3a).

The presence of high concentrations of soluble $\mathrm{Fe}$ in the pore water of the alder carr and clay soils right from the start of the experiment (Fig. 3b) showed that conditions were anoxic from the beginning. Concentrations of $\mathrm{Fe}$ in the pore water correlated with those of amorphous iron in the soil determined by oxalate extraction. In the floating fen soil, hardly any iron was present in the pore water. In the clay soil, the Fe concentration in the pore water stabilised at $400 \mu \mathrm{mol} 1^{-1}$. In the alder carr soil, concentrations were extremely high, varying between 1,500 and $2,500 \mu \mathrm{mol}^{-1}$. Concentrations of $\mathrm{Fe}$ in the surface water remained low, except for the alder carr soil 
Table $3 P$ values of the time effects (time), time $\times$ soil interactions (time $\times$ soil), time $\times$ treatment interactions (time $\times$ treat) and time $\times$ soil $*$ treatment interactions

(time $\times$ soil $\times$ treat) of the pore water and surface water concentrations in the aquarium experiment, as tested by repeated measures (GLM)

\begin{tabular}{|c|c|c|c|c|}
\hline & Time & Time $\times$ Soil & Time $\times$ Treat & Time $\times$ Soil $\times$ Treat \\
\hline \multicolumn{5}{|l|}{ Pore water } \\
\hline $\mathrm{P}$ & 0.00 & 0.00 & 0.55 & 0.83 \\
\hline $\mathrm{Fe}$ & 0.00 & 0.00 & 0.01 & 0.00 \\
\hline $\mathrm{Ca}$ & 0.01 & 0.00 & 0.59 & 0.36 \\
\hline $\mathrm{NH}_{4}$ & 0.00 & 0.00 & 0.35 & 0.08 \\
\hline $\mathrm{Cl}$ & 0.00 & $\mathbf{0 . 0 0}$ & 0.69 & 0.31 \\
\hline $\mathrm{Na}$ & 0.00 & 0.00 & 0.00 & 0.12 \\
\hline $\mathrm{K}$ & 0.00 & 0.00 & 0.83 & 0.96 \\
\hline $\mathrm{SO}_{4}$ & 0.00 & 0.00 & 0.00 & 0.00 \\
\hline $\mathrm{PO}_{4}$ & 0.00 & 0.00 & 0.25 & 0.48 \\
\hline $\mathrm{Mn}$ & 0.00 & 0.00 & 0.07 & 0.27 \\
\hline $\mathrm{Mg}$ & 0.01 & 0.00 & 0.57 & 0.56 \\
\hline $\mathrm{pH}$ & 0.00 & 0.00 & 0.04 & 0.27 \\
\hline Alkalinity & 0.00 & 0.00 & 0.03 & 0.42 \\
\hline \multicolumn{5}{|c|}{ Surface water } \\
\hline $\mathrm{P}$ & 0.00 & 0.00 & 0.17 & 0.06 \\
\hline $\mathrm{Fe}$ & 0.00 & 0.00 & 0.06 & 0.39 \\
\hline $\mathrm{Ca}$ & 0.00 & 0.00 & 0.37 & 0.32 \\
\hline $\mathrm{NH}_{4}$ & 0.00 & 0.00 & 0.00 & 0.02 \\
\hline $\mathrm{Cl}$ & 0.00 & 0.03 & 0.40 & 0.65 \\
\hline $\mathrm{Na}$ & 0.00 & 0.00 & 0.00 & 0.32 \\
\hline $\mathrm{K}$ & 0.00 & 0.00 & 0.32 & 0.08 \\
\hline $\mathrm{SO}_{4}$ & 0.00 & 0.00 & 0.00 & 0.24 \\
\hline $\mathrm{PO}_{4}$ & 0.00 & 0.00 & 0.03 & 0.01 \\
\hline $\mathrm{Mn}$ & 0.00 & 0.02 & 0.00 & 0.06 \\
\hline $\mathrm{Mg}$ & 0.00 & 0.00 & 0.67 & 0.25 \\
\hline $\mathrm{pH}$ & 0.00 & 0.00 & 0.06 & 0.12 \\
\hline Alkalinity & 0.00 & 0.00 & 0.01 & 0.47 \\
\hline
\end{tabular}

Bold values indicate $P \leq 0.05$ trations were high for the clay soil, but fell considerably within the first month. The sulphide concentration in the pore water after 28 weeks was below the detection limit for all soils and treatments, except for the sulphate-treated floating fen soil (275 $\mu \mathrm{mol} \mathrm{l}^{-1}$; results not shown).

Starting from week 29, the distance between the floating sods and the bottom of the aquarium became significantly smaller in the sulphate-treated condition (Figs. 4 and 5). Sulphate addition had a significant influence on the $\mathrm{CH}_{4}$ concentrations of the pore water in the floating fen soil. Average pore water concentration in the control was $1,700 \mu \mathrm{mol} \mathrm{CH}_{4} \mathrm{l}^{-1}$ pore water, against $370 \mu \mathrm{mol} 1^{-1}$ for the sunken sods in the sulphate treatment (results not shown). 
Initial phosphate concentrations in the pore water were high for the fen soil (Fig. 3e), but decreased strongly within the first 2 weeks. Phosphate concentrations in the surface water of all soils (results not shown) also showed a steep drop at the beginning of the experiment, due to leaching. Concentrations of total P (results not shown) showed the same pattern as phosphate concentrations. Phosphate concentrations in the pore water became high especially in the alder carr soil after 10 weeks $\left(13-20 \mu \mathrm{mol} \mathrm{PO}_{4} \mathrm{l}^{-1}\right.$ (Fig. 3e), 17-42 $\mu \mathrm{mol}$ total $\mathrm{P}^{-1}$ ), compared to the other soil types. Sulphate addition clearly increased the phosphate availability in the pore water of the iron-rich alder carr soil, unlike the other soils. Phosphate concentrations in the pore water of this soil upon treatment with sulphate were significantly higher than in the control (weeks 6-20; about twice as high in week 20). In the surface water, however, this effect of sulphate on phosphate concentrations was only visible as a transient peak in week 20 , when surface water concentrations $\left(31 \mu \mathrm{mol} \mathrm{l}^{-1}\right)$ were 10 times higher in the sulphate-treated condition (results not shown).

$\mathrm{NO}_{3}^{-}$was present in very low concentrations from the start of the experiment (results not shown). Within 2 weeks, it dropped to below $5 \mu \mathrm{mol} 1^{-1}$ in both the pore water and the surface water, either by reduction under anoxic circumstances, or by leachout. During the experiment, concentrations of $\mathrm{NH}_{4}^{+}$in the pore water (Fig. 3f) were high in the clay and the floating fen soil (10-100 $\left.\mu \mathrm{mol} \mathrm{l}^{-1}\right)$, and extremely high in the alder carr soil (up to $1,600 \mu \mathrm{mol}^{-1}$ ).

As the reduction of $\mathrm{Fe}$ and that of $\mathrm{SO}_{4}$ are acid consuming processes, the $\mathrm{pH}$ in the pore water (Fig. $3 \mathrm{~g}$ ) rose in all soils during the experiment, the increase being greater for the sulphate treatment (time $\times$ treatment interaction). $\mathrm{pH}$ also increased in the surface water during the experiment (results not shown). During algal blooms, $\mathrm{pH}$ rose above 9 in the surface water of the alder carr soil, as a result of $\mathrm{CO}_{2}$ depletion by photosynthesis.

\section{Biomass of the phytometers}

In the floating fen soil, the addition of sulphate had a negative effect on $G$. maxima biomass production. Here, the addition reduced the biomass by more than $60 \%$ compared to the control (results not shown). In the other soils, however, standard deviations of the 

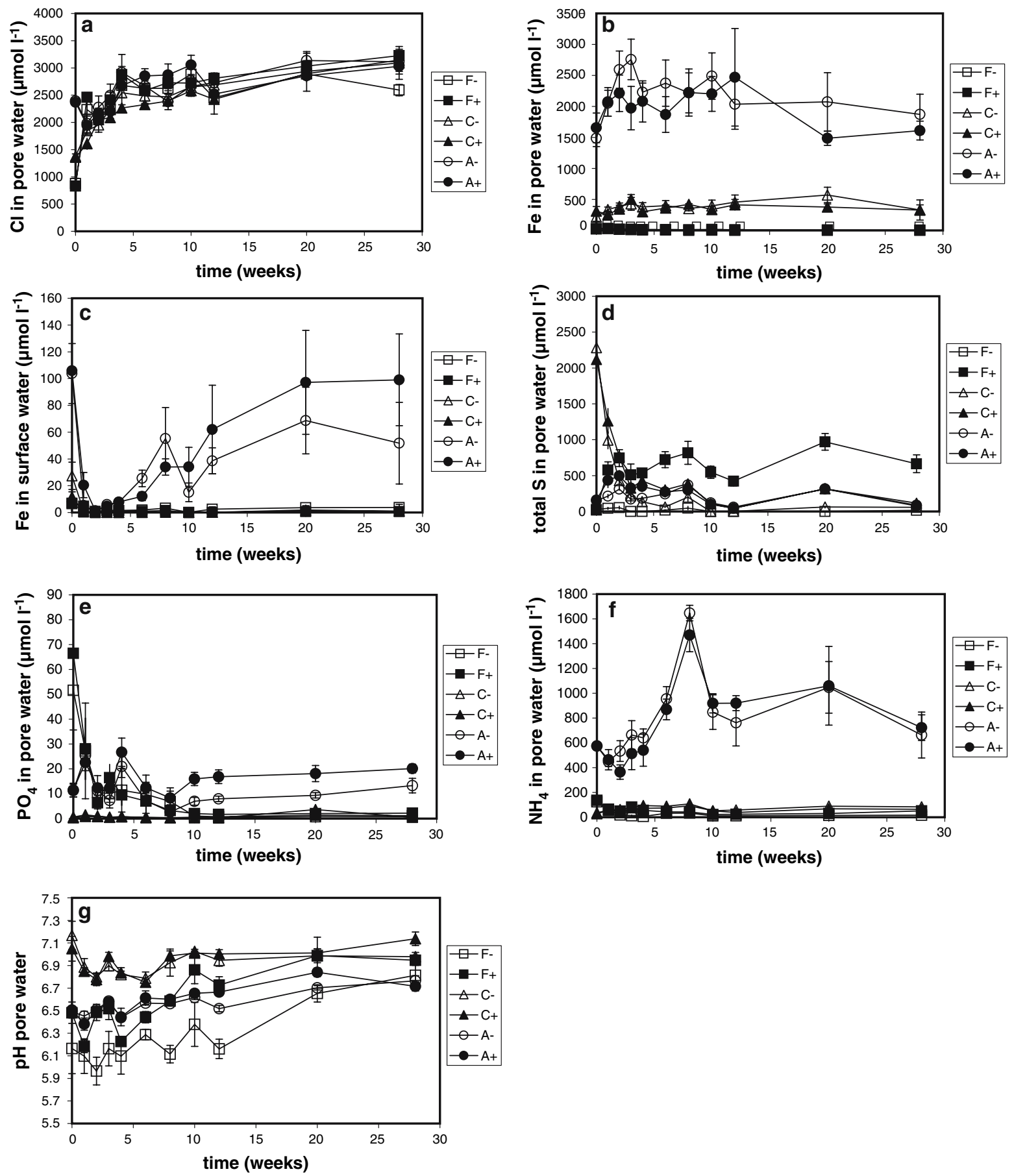

Fig. 3 Concentrations of ions in the pore water and the surface water in the aquarium experiments. Open symbols represent treatments without sulphate, closed symbols treatments with added sulphate. Squares: floating fen soil $(\mathrm{F})$; triangles: clay soil (C); circles: alder carr soil (A). Error bars represent standard error of the mean. (a) Concentration of $\mathrm{Cl}$ in the pore

water; (b) concentration of $\mathrm{Fe}$ in the pore water; (c) concentration of $\mathrm{Fe}$ in the surface water; (d) concentration of total $\mathrm{S}$ in the pore water; (e) concentration of $\mathrm{PO}_{4}$ in the pore water; (f) concentration of $\mathrm{NH}_{4}$ in the pore water; $(\mathbf{g}) \mathrm{pH}$ of the pore water 


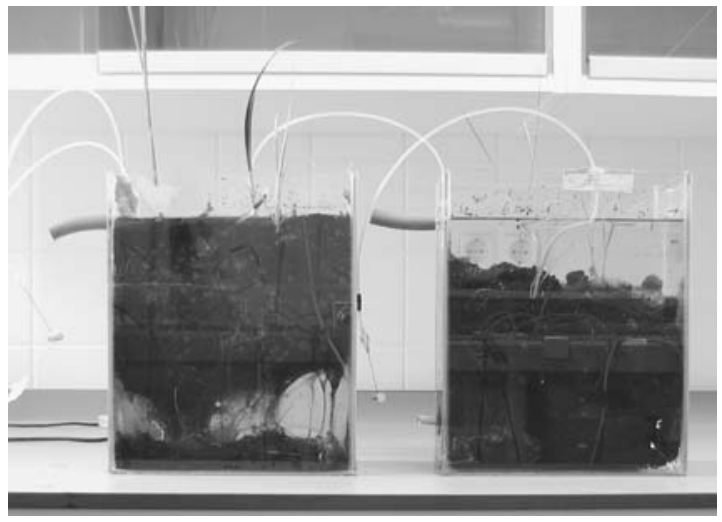

Fig. 4 Floating fen soil sinking under the influence of sulphate addition. Control treatment on the left, treatment with sulphate on the right. Also visible are the smaller G. maxima plants in the sulphate treatment

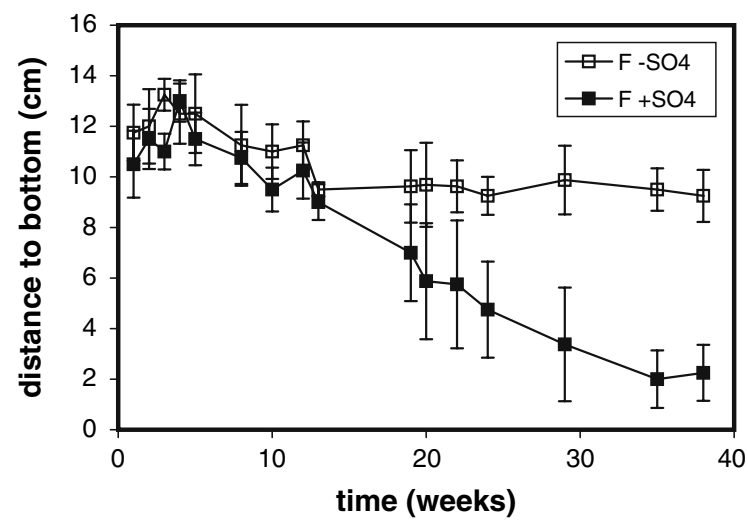

Fig. 5 Distance of floating fen rafts from the bottom of the aquaria. $\mathrm{F}=$ floating fen, $-\mathrm{SO}_{4}=$ control treatment without sulphate, $+\mathrm{SO}_{4}=$ treatment with sulphate. Error bars represent standard error of the mean

biomass were too large to identify significant differences between the treatments. This was due to die-off of part of the plants as a consequence of their being planted below the water table in these soils. In the floating fen soil, a significant difference in iron concentration in the plant tissue of $L$. minor was found between the treatments (lower in the sulphate treatment), but this did not affect biomass production (results not shown). G. maxima did not show lower iron concentrations in the sulphate treatment. Concentrations of other important elements in the phytometer biomass, such as $\mathrm{N}$ and $\mathrm{P}$, showed no significant effect of the sulphate treatment.
Decomposition experiment

\section{Potential decomposition}

Potential decomposition rates (Fig. 6, total C) were highest in the floating fen soil. No significant effect of sulphate addition on the potential decomposition rates was found. When corrected for the organic matter content of the soils, decomposition rates in the floating fen soil were four times higher than the rates in the alder carr soil.

\section{Potential production of $\mathrm{CH}_{4}$}

The potential methane production differed considerably between the three soil types. Hardly any methane was produced in the clay soil. In contrast, the floating fen soil had a very high potential methane production rate (about $9 \mu \mathrm{mol} \mathrm{g}^{-1}$ dry weight day ${ }^{-1}$; Fig. 6), which was four times higher than the potential methane production rate in the alder carr slurry. Univariate ANOVA showed that the two organic soils also differed in the duration of the lag phase, i.e. the initial phase in which no methane is produced ( $4 \mathrm{~h}$ for the floating fen soil and $215 \mathrm{~h}$ for the alder carr soil). A significant effect of the addition of sulphate on the methane production rates was also demonstrated by univariate ANOVA (Table 5), showing the inhibiting effects of sulphate as a more favourable electron acceptor.

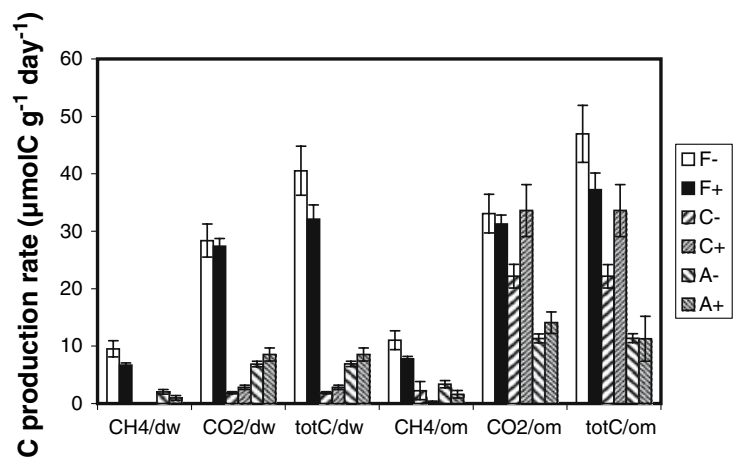

Fig. 6 Potential $\mathrm{CO}_{2}$ and $\mathrm{CH}_{4}$ and total $\mathrm{C}\left(\mathrm{CO}_{2}+\mathrm{CH}_{4}\right)$ production rates in the decomposition experiment for the various soils and treatments, expressed per gram dry weight (/ $\mathrm{dw}$ ) as well as per gram organic matter (/om). F = floating fen, $\mathrm{C}=$ clay soil, $\mathrm{A}=$ alder carr soil $-\mathbf{-}=$ control treatment without sulphate, $+=$ treatment with sulphate. Error bars represent standard error of the mean. 
Table $5 P$ values of the soil and treatment effects of the $\mathrm{CO}_{2}$, $\mathrm{CH}_{4}$ and total $\mathrm{C}\left(\mathrm{CO}_{2}+\mathrm{CH}_{4}\right)$ production rates expressed per gram dry weight, as tested by univariate ANOVA (GLM)

\begin{tabular}{llll}
\hline & $\begin{array}{l}\mathrm{CO}_{2} \\
\text { production } \\
\text { rate }\end{array}$ & $\begin{array}{l}\mathrm{CH}_{4} \\
\text { production } \\
\text { rate }\end{array}$ & $\begin{array}{l}\text { TotalC } \\
\text { production rate }\end{array}$ \\
\hline soil & $\mathbf{0 . 0 0 0}$ & $\mathbf{0 . 0 0 0}$ & $\mathbf{0 . 0 0 0}$ \\
treatment & 0.357 & $\mathbf{0 . 0 2 1}$ & 0.605 \\
soil $\times$ treatment & 0.537 & 0.138 & $\mathbf{0 . 0 4 3}$ \\
\hline
\end{tabular}

Bold values indicate $P \leq 0.05$

\section{Potential production of $\mathrm{CO}_{2}$}

Like that of $\mathrm{CH}_{4}$, the potential production rate of $\mathrm{CO}_{2}$ in the floating fen slurry was very high $\left(28 \mu \mathrm{mol} \mathrm{g}{ }^{-1}\right.$ dry weight day ${ }^{-1}$; Fig. 6), four times higher than the potential production rate in the alder carr slurry. In the clay slurry, $\mathrm{CO}_{2}$ production was measured in the first 6 days of the experiment, but the production stopped after that time. Although the potential production rate expressed per gram dry weight was three times smaller in this clay slurry than in the alder carr slurry, when expressed as potential production rate per gram organic matter, the potential $\mathrm{CO}_{2}$ production rate in the clay slurry during these six days was even higher than in that of the alder carr.

\section{Potential release rates}

Figure $7 \mathrm{a}-\mathrm{d}$ shows the net potential release rates for $\mathrm{PO}_{4}, \mathrm{NH}_{4}, \mathrm{~K}$ and $\mathrm{Fe}$. Both of the organic soils ( $\mathrm{F}$ and A), had high net $\mathrm{PO}_{4}, \mathrm{NH}_{4}$ and $\mathrm{K}$ release rates. Net Fe release was highest in the alder carr slurry, analogous to the aquarium experiment. The ratio between the net release of $\mathrm{C}$ and $\mathrm{NH}_{4}$ in the slurry was three times higher in the floating fen soil than in the alder carr soil. In the alder carr slurry treated with sulphate, phosphate release was three times higher $(P=0.021)$ than in the control. This is comparable to the results of the aquarium experiment. In the iron-poor floating fen soil, the iron release rate was significantly reduced by the addition of sulphate.

\section{Discussion}

The three soil types showed large differences in potential anaerobic decomposition rates and release rates. In the clay soil, $\mathrm{CO}_{2}$ production stopped after 6 days. The potential decomposition rate per gram of organic matter in these first days was, however, even higher in this soil than in the alder carr soil. This means that during the first 6 days, easily degradable organic matter was present in the clay soil. Most likely, after a few days the concentration of degradable organic matter had become limiting for decomposition in the clay soil. The potential decomposition rate of the floating fen soil was very high (40 $\mu \mathrm{mol} \mathrm{C} \mathrm{g}^{-1} \mathrm{dw}$ day $^{-1}$ ). Maximum values found in the literature vary between $10 \mu \mathrm{mol} \mathrm{C} \mathrm{g}{ }^{-1} \mathrm{dw}_{\mathrm{day}^{-1}}$ for bog peat (Smolders et al. 2002) and $50 \mu \mathrm{mol} \mathrm{C} \mathrm{g}{ }^{-1} \mathrm{dw} \mathrm{day}^{-1}$, reported for the floating fen in Lake Emlagharan in Ireland (Bontes et al. 2005). This means that the organic matter in the floating fen soil was relatively easily degradable. Potential $\mathrm{CH}_{4}$ production rates also varied per soil type. Due to the lack of easily decomposable organic material, no $\mathrm{CH}_{4}$ was produced in the clay soil, i.e. there was a surplus of electron acceptors compared to the organic matter present. This was also the case in the alder carr soil during the lag phase. The high concentration of $\mathrm{Fe}(\mathrm{III})$ in this soil inhibited methanogenesis in this phase, because iron-reducing bacteria have a higher affinity to easily degradable organic compounds, such as acetate, than methane-producing bacteria (Roden and Wetzel 2003). The presence of a lag phase suggests that methanogenesis does not occur in the field, because of the continuous supply of sulphate.

Release rates were high for both of the organic soils. The alder carr soil released more iron, due to its higher amorphous iron concentration. The ratio between the net release of $\mathrm{C}$ and $\mathrm{N}$ in the alder carr slurry was, however, four times lower than in the floating fen soil, although $\mathrm{NH}_{4}^{+}$release rates were equally high: this means that part of the ammonium released in the alder carr soil probably did not originate from the decomposition of organic matter, but from cation exchange. Cation exchange rates might be higher in the alder carr soil than in the other soils, because of the production of high concentrations of $\mathrm{Fe}^{2+}$ by the reduction of $\mathrm{Fe}^{3+}$.

In the aquarium experiment, iron concentrations in the pore water were extremely high in the alder carr soil. Lucassen et al. (2000) showed that field concentrations of 2,600 $\mu \mathrm{mol} \mathrm{Fe} 1^{-1}$ induce necrotic spots in leaves of Glyceria fluitans. Although no such 
(a)
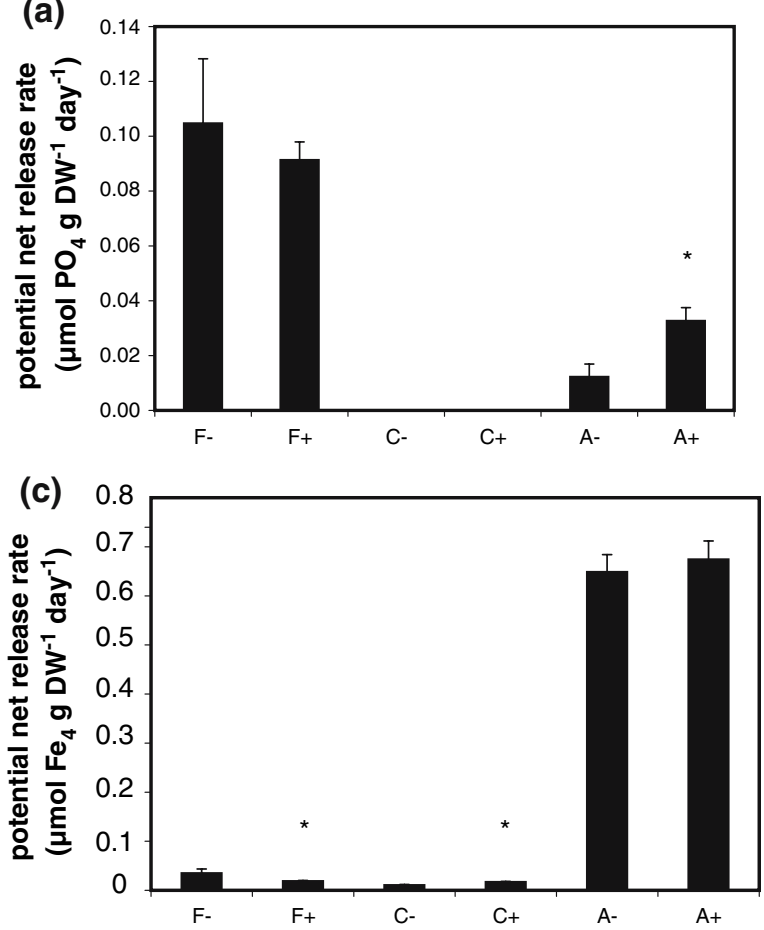

Fig. 7 Potential net release rates in the decomposition experiment. $\mathrm{F}=$ floating fen, $\mathrm{C}=$ clay soil, $\mathrm{A}=$ alder carr soil. $-=$ control treatment without sulphate,$+=$ treatment with sulphate. Error bars represent standard error of the mean. (a)

spots were found on Glyceria maxima in our experiment, concentrations found in our experiment (up to 2,500 $\mu \mathrm{mol} \mathrm{Fe} \mathrm{l}^{-1}$ ) might still be toxic to sensitive plant species in the field. It is known that reduced iron from the soil pore water that diffuses towards the surface water is oxidised and precipitates on the soilsurface water interface due to the higher redox potential of the water column (Cornwell and Kipphut 1992; Gunnars and Blomqvist 1997; Moore et al. 1998). This explains the low iron concentrations in the surface water over the clay soil. In the alder carr soil, pore water concentrations were so high that exchange of $\mathrm{Fe}$ between the pore water and the surface water took place. Since the surface water was directly connected to the outflow of the aquarium, concentrations in the surface water can be regarded as outflow concentrations. The stability of the pore water iron concentrations and the high weekly iron outflow from the alder carr soil show that iron reduction was still taking place at the end of the experiment. Sulphate reduction rates were also high, (b)

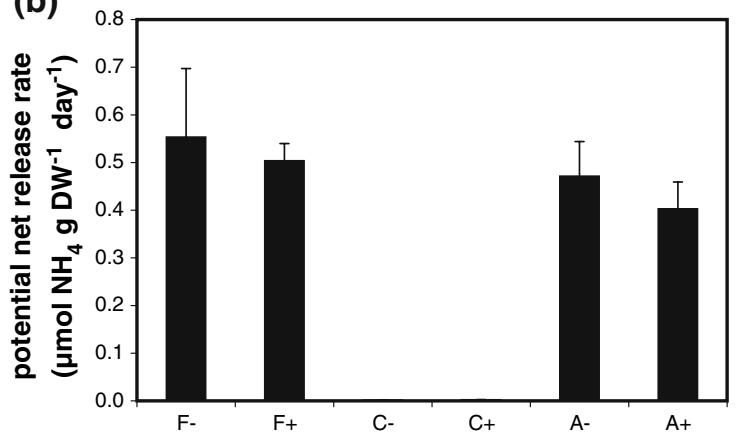

(d)

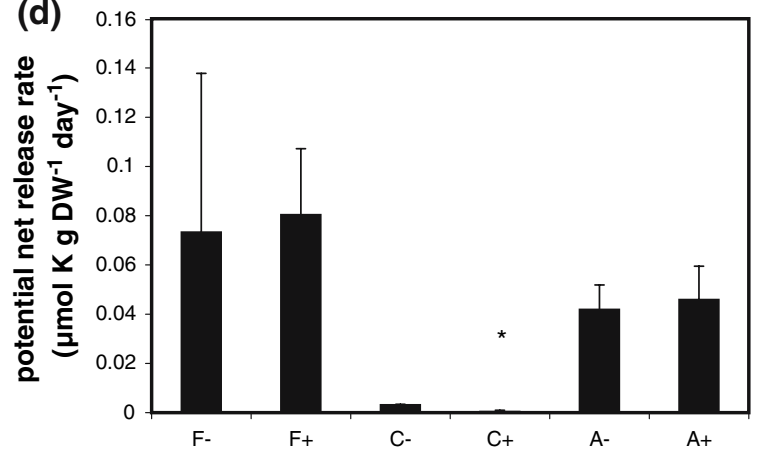

Potential net release rate $\mathrm{PO}_{4}$; (b) potential net release rate $\mathrm{NH}_{4}$; (c) potential net release rate $\mathrm{K}$; (d) potential net release rate Fe. Asterisks mark significant differents between treatments within a soil

indicating simultaneous activity of $\mathrm{Fe}-$ and $\mathrm{SO}_{4}-$ reducing micro-organisms (Sørensen 1982).

Iron reduction played a major role in the mobilisation of phosphate in this experiment. In the alder carr soil, which was rich in iron as well as in total and Olsen-extractable $\mathrm{P}$, continuous iron reduction led to high concentrations of $\mathrm{P}$ in the pore water. In this $\mathrm{P}$ rich soil, $\mathrm{Fe}(\mathrm{III})$ precipitations at the soil-water interface did not trap all $\mathrm{P}$, and increasing $\mathrm{P}$ concentrations were also found in the surface water. In the iron-poor floating fen soil, on the other hand, most of the phosphate release might be attributed to decomposition of organic material. The decomposition experiment showed a high decomposition rate in this soil, as well as high concentrations of phosphate in the slurry at the end of the experiment. There was, however, a striking difference between the high phosphate release in the slurry of the floating fen in the incubation experiment and the low phosphate concentrations in the pore water of the aquarium experiment, whereas the $\mathrm{P}$ concentrations in the alder 
carr were high in both experiments. One of the explanations for this apparent discrepancy might be the difference in phosphate leach-out between these soils. Pore water phosphate concentrations in the floating fen soil were high at the beginning of the aquarium experiment, but decreased very fast after the start of the experiment. Smolders et al. (2001) showed that the release of phosphate from the pore water of underwater soils to the water layer strongly depends on the $\mathrm{Fe}: \mathrm{PO}_{4}$ ratio in the pore water; below a value of $1\left(\mathrm{~mol} \mathrm{~mol}^{-1}\right)$, they measured a strong release of $\mathrm{PO}_{4}$ to the surface water. $\mathrm{Fe}: \mathrm{PO}_{4}$ ratios in our experiment were 0.3 (with sulphate) to 5 (without sulphate) for the floating fen soil and 82 (with sulphate) to 176 (without sulphate) for the alder carr soil. This may have caused a higher phosphate release to the water layer from the floating fen soil, and hence a larger leach-out.

Due to the anaerobic conditions, $\mathrm{NH}_{4}^{+}$resulting from the decomposition of organic matter could not be nitrified, and accumulated in the pore water, particularly in the alder carr soil. Another possible source of the high $\mathrm{NH}_{4}^{+}$concentrations in the pore water could be cation exchange of adsorbed $\mathrm{NH}_{4}^{+}$by cations added with the artificial river water (Lucassen et al. 2006), and in the alder carr soil also by the mobilised $\mathrm{Fe}^{2+}$ originating from the reduction of $\mathrm{Fe}(\mathrm{III})$ oxides. In the alder carr soil, ammonium concentrations rose to $1,600 \mu \mathrm{mol} \mathrm{l}^{-1}$. Lucassen et al. (2006) showed that the presence of target vegetation in alder carrs is correlated with low concentrations of ammonium $\left(<200 \mu \mathrm{mol} \mathrm{l}^{-1}\right)$. Hence, the concentrations measured in this experiment, if present in the field, could seriously hamper the intended vegetation development.

The response of the different soils used in this study to inundation with sulphate-rich river water in the aquarium experiment varied substantially, reflecting their soil characteristics. Sulphide, produced by reduction of the added sulphate, was present in excess relative to iron in the floating fen soil. Hence, the binding of sulphide to iron reduced the availability of soluble iron in this soil, both in the aquarium and in the incubation experiment. As iron concentrations were low, phosphate release as a result of the binding of iron to sulphide was equally low. Part of the sulphide produced could not be bound to iron and was freely available in the pore water in toxic concentrations, hampering the growth of the planted Glyceria maxima. The sulphide concentrations we measured in the pore water have been shown to be toxic to several wetland plants (Smolders and Roelofs 1996; Van der Welle et al. 2006, 2007). Moreover, the addition of sulphate decreased the methane concentration in the floating fen soil in the aquarium experiment and the potential methane production rate in the incubation experiment. Methane concentrations determined the buoyancy of the floating fen, just as had been demonstrated earlier for other floating fens and peat bog rafts (Hogg and Wein 1988a; Swarzenski et al. 1991; Sasser et al. 1996; Lamers et al. 1999; Smolders et al. 2002). The floating fen soil sank under the influence of sulphate as a result of methanogenic bacteria being outcompeted by sulphate-reducing bacteria (Cappenberg 1974; Abram and Nedwell 1978; Lovley and Klug 1983; Westermann and Ahring 1987; Prieme 1994; Scholten and Stams 1995), in the same way as this is known to happen in floating peat bogs (Lamers et al. 1999; Smolders et al. 2002). In the other soils, sulphide formed by the reduction of sulphate was bound to the excess iron. In both the aquarium experiment and the incubation experiment, this led to an additional release of phosphate in the alder carr soil. Sulphate addition did not increase the decomposition rates, as had been found earlier in bog peat (Lamers et al. 1999; Smolders et al. 2002; Tomassen et al. 2003). In soils where sulphate increases decomposition, this seems to be an effect of the increased alkalinity produced by the reduction of sulphate (Lamers et al. 1999; Smolders et al. 2002; Tomassen et al. 2003). In our experiment, alkalinity of the artificial river water was already high $\left(2,000 \mu \mathrm{mol} \mathrm{HCO}_{3}^{-} \mathrm{l}^{-1}\right.$, similar to concentrations in the water of the river Meuse). Since no effect of sulphate on the decomposition rate was found, it is likely that the additional release of phosphate in the sulphate treatment of the alder carr soil in the incubation experiment did not originate from decomposition of organic matter, but can be attributed to the competition between sulphide and phosphate for binding to iron.

Our findings show the importance of both soil type and water quality in the biogeochemical response to flooding. Inundation has the smallest impact on soils without organic matter, in terms of phosphate release by reduction of $\mathrm{Fe}$ (III) and the formation of potentially phytotoxic reduced compounds such as ammonium, $\mathrm{Fe}$ (II) and sulphide ('internal toxification'). Flooding of 
soils containing organic matter, in contrast, leads to accumulation of ammonium and release of Fe-bound phosphate. This internal eutrophication could cause algal blooms in the water layer above such soils. Additionally, river water polluted with sulphate may cause sulphide phytotoxicity if the iron content is low, as was shown here for the floating fen soil. If the soil is richer in iron, sulphide will be bound to iron and may release phosphate that was bound to the iron, as took place in the alder carr soil. It should be noted that these two processes, sulphide toxicity and enhanced phosphate mobilisation, can also take place in the same soil, as was found for instance by Lamers et al. (1998) for a mesotrophic fen.

The presence of sulphate reduces methanogenesis, which is a very important process in ecosystems depending on methane for floating, such as floating fen mats and bog peat rafts. Floating fen mats form the first stage in the terrestrialisation process in fen systems. Our results show that inundation of these floating fens with sulphate-rich river water at levels occurring in the rivers Meuse and Rhine may thus destroy the floating fens and their rare vegetation as well as block the subsequent terrestrialisation process and the accompanying vegetation succession. Analogously, we expect the elevated nitrate concentrations in the river water to have a similar inhibiting effect on methanogenesis (Westermann and Ahring 1987; Scholten and Stams 1995) and on the buoyancy of floating fens.

The results presented in this article have important implications for the rehabilitation and creation of wetlands, and for the selection of locations for the creation of flood water storage areas. Completely mineral soils, such as those in clay and sand sedimentation areas where the topsoil has been removed, are not likely to be at great risk of eutrophication in the short term. However, wetland locations containing organic matter-and most soils do so-should be chosen with greater care. Here, other soil characteristics such as iron and phosphate concentrations, and water quality parameters such as sulphate concentrations, should be taken into account.

Acknowledgements We would like to thank Martin Versteeg for his help in collecting the soils, Roy Peters and Germa Verheggen for their technical support, and Jelle Eygensteyn for his help with the analyses. We thank Jan Klerkx for improving the English of the text. This study was financially supported by the Netherlands Organisation for Scientific Research (NWO) as a part of the TRIAS programme (project 835.80.010).

\section{References}

Abram JW, Nedwell DB (1978) Inhibition of methanogenesis by sulfate reducing bacteria competing for transferred hydrogen. Arch Microbiol 117:89-92

Beltman B, Van den Broek T, Van Maanen K, Vaneveld K (1996) Measures to develop a rich-fen wetland landscape with a full range of successional stages. Ecol Eng 7:299313

Bontes B, Pijnappel H, Geurts J, Schouwenaars J, Klinge M, Verberk W, Lamers L (2005) Onderzoek ten behoeve van het herstel en beheer van Nederlandse laagveenwateren tussentijdse OBN-rapportage (in Dutch). Report Ministry of Agriculture, Nature and Food Quality, The Netherlands

Cappenberg TE (1974) Interrelations between sulfate-reducing and methane-producing bacteria in bottom deposits of a freshwater lake. 1. Field Observations. Antonie Van Leeuwenhoek J Microbiol 40:285-295

Caraco NF,Cole JJ, Likens GE (1989) Evidence for sulphatecontrolled phosphorus release from sediments of aquatic systems. Nature 341:316-318

Cornwell JC, Kipphut GW (1992) Biogeochemistry of manganese-rich and iron-rich sediments in Toolik Lake, Alaska. Hydrobiologia 240:45-59

Gunnars A, Blomqvist S (1997) Phosphate exchange across the sediment-water interface when shifting from anoxic to oxic conditions - an experimental comparison of freshwater and brackish-marine systems. Biogeochemistry 37:203-226

Hogg EH, Wein RW (1988a) Seasonal change in gas content and buoyancy of floating typha mats. J Ecol 76:10551068

Hogg EH, Wein RW (1988b) The contribution of Typha components to floating mat buoyancy. Ecology 69(4):1025-1031

Lamers LPM, Tomassen HBM, Roelofs JGM (1998) Sulfateinduced eutrophication and phytotoxicity in freshwater wetlands. Environ Sci Technol 32:199-205

Lamers LPM, Farhoush C, van Groenendael JM, Roelofs JGM (1999) Calcareous groundwater raises bogs; the concept of ombrotrophy revisited. J Ecol 87:639-648

Lamers LPM, Ten Dolle GE, Van den Berg STG, Van Delft SPJ, Roelofs JGM (2001) Differential responses of freshwater wetland soils to sulphate pollution. Biogeochemistry 55:87-102

Lamers LPM, Falla SJ, Samborska EM, Van Dulken LAR, Van Hengstum G, Roelofs JGM (2002a) Factors controlling the extent of eutrophication and toxicity in sulfate-polluted freshwater wetlands. Limnol Oceanogr 47:585-593

Lamers LPM, Smolders AJP, Roelofs JGM (2002b) The restoration of fens in the Netherlands. Hydrobiologia 478:107-130

Lovley DR, Klug MJ (1983) Sulfate reducers can out-compete methanogens at fresh-water sulfate concentrations. Appl Environ Microbiol 45:187-192

Lucassen ECHET, Smolders AJP, Roelofs JGM (2000) Increased groundwater levels cause iron toxicity in Glyceria fluitans (L.). Aquat Bot 66:321-327

Lucassen ECHET, Smolders AJP, Van de Crommenacker J, Roelofs JGM (2004) Effects of stagnating sulphate-rich 
groundwater on the mobility of phosphate in freshwater wetlands: a field experiment. Arch Hydrobiol 160:117131

Lucassen ECHET, Smolders AJP, Boedeltje G, van den Munckhof PJJ, Roelofs JGM (2006) Groundwater input affecting plant distribution by controlling ammonium and iron availability. J Veget Sci 17:425-434

Moore PA, Reddy KR, Fisher MM (1998) Phosphorus flux between sediment and overlying water in Lake Okeechobee, Florida: Spatial and temporal variations. J Environ Qual 27:1428-1439

Olsen SR, Cole CV, Watanabe FS, Dean LA (1954) Estimation of available phosphorus in soils by extraction with sodium bicarbonate. U.S. Dep. of Agric. Circ. 939

Patrick WH, Khalid RA (1974) Phosphate release and sorption by soils and sediments - effect of aerobic and anaerobic conditions. Science 186:53-55

Pollux BJA, Pollux PMJ (2004) Fish and waterfowl mortality at Romeinenweerd due to cyanobacterial bloom (in Dutch with summary in English), Natuurhistorisch Maandblad 93:207-209

Prieme A (1994) Production and emission of methane in a brackish and a fresh-water wetland. Soil Biol Biochem 26:7-18

Roden EE, Edmonds JW (1997) Phosphate mobilization in iron-rich anaerobic sediments: microbial $\mathrm{Fe}(\mathrm{III})$ oxide reduction versus iron-sulfide formation. Arch Hydrobiol 139:347-378

Roden EE, Wetzel RG (2003) Competition between Fe(III)reducing and methanogenic bacteria for acetate in ironrich freshwater sediments. Microb Ecol 45:252-258

Roelofs JGM (1991) Inlet of alkaline river water into peaty lowlands - effects on water-quality and Stratiotes aloides L. stands. Aquat Bot 39:267-293

Sasser CE, Gosselink JG, Swenson EM, Swarzenski CM, Leibowitz NC (1996) Vegetation, substrate and hydrology in floating marshes in the Mississippi river delta plain wetlands, USA. Vegetatio 122:129-142

Scholten JCM, Stams AJM (1995) The effect of sulfate and nitrate on methane formation in a freshwater sediment. Antonie Van Leeuwenhoek Int J Gen Mol Microbiol 68:309-315

Schwertmann U (1964) Differenzierung der Eisenoxide des Bodens durch photochemische Extraction mit saurer Ammoniumoxalat-Loesung. Zeitschrift für Pflanzenernährung, Düngung und Bodenkunde 105:194202

Smolders AJP, Roelofs JGM (1996) The roles of internal iron hydroxide precipitation, sulphide toxicity and oxidizing ability in the survival of Stratiotes aloides roots at different iron concentrations in sediment pore water. New Phytol 133:253-260

Smolders AJP, Roelofs JGM, Den Hartog C (1996) Possible causes for the decline of the water soldier (Stratiotes aloides L.) in the Netherlands. Arch Hydrobiol 136:327342

Smolders AJP, Lamers LPM, Moonen M, Zwaga K, Roelofs JGM (2001) Controlling phosphate release from phos- phate-enriched sediments by adding various iron compounds. Biogeochemistry 54:219-228

Smolders AJP, Tomassen HBM, Lamers LPM, Lomans BP, Roelofs JGM (2002) Peat bog restoration by floating raft formation: the effects of groundwater and peat quality. $\mathrm{J}$ Appl Ecol 39:391-401

Smolders AJP, Lamers LPM, Den Hartog C, Roelofs JGM (2003) Mechanisms involved in the decline of Stratiotes aloides L. in The Netherlands: sulphate as a key variable. Hydrobiologia 506:603-610

Sørensen J (1982) Reduction of ferric iron in anaerobic, marine sediment and interaction with reduction of nitrate and sulfate. Appl Environ Microbiol 43:319-324

Swarzenski CM, Swenson EM, Sasser CE, Gosselink JG (1991) Marsh mat flotation in the Louisiana Delta Plain. J Ecol 79:999-1011

Tallis JH (1973) The terrestrialization of lake basins in North Cheshire, with special reference to the development of a 'Schwingmoor' structure. J Ecol 61(2):537-567

Tomassen HBM, AJP Smolders JM van Herk LPM Lamers JGM Roelofs (2003) Restoration of cut-over bogs by floating raft formation: An experimental feasibility study. Appl Veget Sci 6:141-152

Van den Brink FWB (1994) Impact of hydrology on floodplain lake ecosystems along the lower Rhine and Meuse. Dissertation, University of Nijmegen, the Netherlands

Van den Brink FWB, Van der Velde G, Bijdevaate A (1991) The (semi)aquatic vegetation of still waters within the floodplains of the rivers Rhine and Meuse in The Netherlands: historical changes and the role of inundation. Verh Int Verein Limnol 24:2693-2699

Van der Welle MEW, Cuppens MLC, Lamers LPM, Roelofs JGM (2006) Detoxifying toxicants: interactions between sulphide and iron toxicity. Environ Toxicol Chem 25(6):1592-1597

Van der Welle MEW, Niggebrugge K, Lamers LPM, Roelofs JGM (2007) Differential responses of the freshwater wetland species Juncus effusus L. and Caltha palustris L. to iron supply in sulphidic environments. Environ Pollut 147(1):222-230

Van der Weijden CH, Middelburg JJ (1989) Hydrogeochemistry of the river Rhine - Long-term and seasonal variability, elemental budgets, base levels and pollution. Water Res 23:1247-1266

Van Donselaar J (1961) On the vegetation of former River Beds in the Netherlands. Wentia 5:1-85

Van Gemerden H (1984) The sulfide affinity of phototrophic bacteria in relation to the location of elemental sulfur. Arch Microbiol 139:289-294

Waterstat (2006) Dutch Ministry of Transport, Public Works and Water Management, www.waterstat.nl. Cited 8 May 2006

Westermann P, Ahring BK (1987) Dynamics of methane production, sulfate reduction, and denitrification in a permanently waterlogged alder swamp. Appl Environ Microbiol 53:2554-2559 